\title{
Genetic variability for synthesis of bioactive compounds in peppers (Capsicum annuum) from Brazil
}

\author{
Henrique Kuhn Massot PADILHA ${ }^{1 *}$, Elisa dos Santos PEREIRA ${ }^{1}$, Priscila Cardoso MUNHOZ ${ }^{1}$, \\ Márcia VIZZOTTO², Ricardo Alexandre VALGAS², Rosa Lía BARBIERI²
}

\begin{abstract}
The objective of this study was to evaluate the genetic variability for synthesis of bioactive compounds in pepper (Capsicum annuum, Solanaceae). Total phenolics, anthocyanins, carotenoids and antioxidant activity were evaluated in 14 accessions of Capsicum annuum from the Capsicum Genebank of Embrapa Temperate Agriculture (Pelotas - RS, Brazil). Thirty plants of each accession were cultivated in the field during spring and summer. The experimental design was a complete randomized block with 14 treatments (accessions) and three replications. The laboratory evaluations followed the same experimental design to field, but with two repetitions more. Seeds were discarded and opposite longitudinal portions of fruits were manually prepared for chemical analyzes. The data obtained showed high genetic variability for phenolics, anthocyanins, carotenoids and antioxidant activity. The P39, P77, P119, P143 and P302 accessions exhibited the highest levels of antioxidants, which are strongly indicated to be used in breeding programs of Capsicum peppers.
\end{abstract}

Keywords: Solanaceae; genetic resources; ex situ conservation; characterization.

Practical Application: Capsicum accessions can be introduced into human diet due to their functional properties and health benefits.

\section{Introduction}

The Capsicum peppers (Solanaceae) are widely appreciated in the culinary as a spice. Peppers can be consumed fresh or processed, as sauces, preserves or dehydrated powder. In industry, its pigments, aromas and pungent substances are widely used (Lutz \& Freitas, 2008).

Among the species of genus, Capsicum annuum is the most worldwide cultivated (Hwang et al., 2013) and includes peppers, sweet peppers for paprika, bell peppers, hot peppers like jalapeño, cayenne, serrano, cherry and many others (Carvalho \& Bianchetti, 2008; Büttow et al., 2010; Alvarez-Parrilla et al., 2012).

Peppers are an important source of nutrients in human diet (Shetty et al., 2013; Moraes et al., 2013). Capsicum annuum is characterized by its high levels of vitamin C (ascorbic acid), provitamin A (carotene) and calcium. Ingestion of 50-100 g fresh pepper fruits can provide about $100 \%$ and $60 \%$ of the recommended daily amounts of vitamin $\mathrm{C}$ and $\mathrm{A}$, respectively. Ripe fruits of pepper are also rich in compounds with antioxidant and anticancer action (Mateos et al., 2013).

Free radicals are harmful to humans, leading to inflammation, tissue damage and disease development. Antioxidants are usually found in fruits and vegetables and thus its consumption has been associated with protection against several non-communicable diseases (Alvarez-Parrilla et al., 2012). Peppers are rich in antioxidants, including chlorophyll, carotenoids, tocopherols and capsaicinoids (Ornelas-Paz et al., 2010). Furthermore, produce neutral and acids phenolic antioxidants, which are important in plant defense responses (Shetty et al., 2013).

Phenolic compounds are secondary metabolites synthesized by plants, both during normal development or in response to stress conditions (Morales-Soto et al., 2013). Polyphenols act in defense against biotic (fungi, bacteria and insects) and abiotic stress (drought, metals in soil, ultraviolet radiation) and the composition can be changed in response to stress levels (Park et al., 2012).

In general, has increased the population concern about feed quality, as well as the question of the functional properties of food. Besides the interest of farmers in getting cultivars more productive and resistant to environmental stresses, plant breeders should also develop cultivars presenting high levels of compounds with functional importance for consumer health (Neitzke, 2012).

New sources of genetic variability can be found in accessions from genebanks, to obtain genotypes of interest. However, it is necessary that they are properly characterized to make it easier to use them.

This study aimed to evaluate the genetic variability for synthesis of bioactive compounds (phenolics, anthocyanins, 
carotenoids and antioxidant activity) in fruits of Capsicum annuum from the Capsicum Genebank of Embrapa Temperate Agriculture (Pelotas - RS, Brazil).

\section{Material and methods}

The evaluation was performed by analysis of 14 accessions of C. annuum from Capsicum Genebank of Embrapa Temperate Agriculture (Table 1). The sowing was carried in August 2012 in polystyrene trays for seedlings, containing 72 filled cells with commercial substrate. In October, when the plants had five to seven true leaves, they were transplanted to the experimental field of Embrapa Temperate Agriculture, spaced $0.5 \mathrm{~m}$ between plants and $1.3 \mathrm{~m}$ between rows. The rows were covered with black plastic mulching type, with the objective to make the control of weeds and contribute to the maintenance of soil moisture. The plants were irrigated by drip irrigation system.

The experimental design was a randomized complete block with 14 treatments and three replications. The experimental unit was composed of a row with ten plants. The performed laboratory evaluations followed the same experimental design to field, but with two repetitions more.

In February 2013, ripe fruits of each plant were stored at $-18{ }^{\circ} \mathrm{C}$ in the Laboratory of Food Science and Technology. For analyzes, seeds were discarded and opposite longitudinal portions of fruits were manually prepared. The accessions were characterized for total phenolics, total anthocyanins, total carotenoids and antioxidant activity.

\subsection{Quantification of phenolic compounds}

The quantification of phenolic compounds was determined by the adapted method of Swain \& Hillis (1959). Sample of $5 \mathrm{~g}$ of pepper and $20 \mathrm{ml}$ of solvent (methanol) were homogenized. The samples were centrifuged at 25,000 rpm for 15 minutes. $250 \mathrm{uL}$ of supernatant was collected and to this sample was added $4 \mathrm{ml}$ of distilled water and $250 \mathrm{uL}$ of Folin-Ciocalteu $(0.25 \mathrm{~N})$. The tubes were shaken by vortex and left for 3 minutes to react. Later was added $0.5 \mathrm{~mL}$ of $1 \mathrm{~N} \mathrm{Na}_{2} \mathrm{CO}_{3}$. The tubes were shaken again and left for 2 hours. Absorbance readings were made with a spectrophotometer at wavelength of $725 \mathrm{~nm}$, after it has been reset with methanol control using quartz cuvette. A standard curve of chlorogenic acid was designed and the data were expressed as mg of chlorogenic acid equivalents per $100 \mathrm{~g}$ of sample.

\subsection{Quantification of anthocyanins}

The quantification of anthocyanins was carried out with the adapted method of Fuleki \& Francis (1968). $5 \mathrm{~g}$ of sample were homogenized with $15 \mathrm{ml}$ of solvent (95\% ethanol to $1.5 \mathrm{~N} \mathrm{HCl}$ ) in Ultra-Turrax, at full speed until uniform consistency. The samples were centrifuged during 15 minutes at $25000 \mathrm{rpm}$. One milliliter of the supernatant was placed in falcon tube, and $2 \mathrm{~mL}$ of solvent (95\% ethanol to $1.5 \mathrm{~N} \mathrm{HCl}$ ) were added. The tubes containing the samples and hexane were shaken by vortex and left for 30 minutes, allowing phase separation. Readings were made on spectrophotometer previously reset with solvent extractor. The absorbance was read in quartz cuvette at $535 \mathrm{~nm}$. A standard curve with chlorogenic acid was established and data were expressed as cyanidin-3-glicoside.

\subsection{Quantification of carotenoids}

The quantification of carotenoids was made by the adapted method of Talcott \& Howard (1999). Peppers sample (2.5 g) with ethanol/acetone solution and antioxidant butylated hydroxytoluene (BHT) were homogenized in Ultra-Turrax. The sample was filtered with the aid of paper filter and the process was repeated until complete discoloration of the sample. After filtering, $50 \mathrm{~mL}$ of hexane were added into the sample. After phase separation, the samples were left for 30 minutes, and then were added $25 \mathrm{~mL}$ of distilled water and left for 30 minutes again. Absorbance

Table 1. Accessions of Capsicum annuum peppers from the Capsicum Genebank of Embrapa Temperate Agriculture (Pelotas, RS, Brazil) characterized for the bioactive compounds.

\begin{tabular}{|c|c|c|c|c|c|}
\hline Acessions & Type & Origin & Ripe fruit color & Fruit shape & Pungency \\
\hline P7 & pimenta & Renascença-PR & red & triangular & low \\
\hline $\mathrm{P} 22$ & pimenta & Renascença-PR & red & triangular & medium \\
\hline P39 & pimenta & Farroupilha - RS & red & almost round & medium \\
\hline P58 & pimenta ornamental & $\begin{array}{c}\text { São Lourenço } \\
\text { do Sul - RS }\end{array}$ & red & triangular & low \\
\hline P77 & pimenta negra & Canoinhas - SC & dark red & triangular & medium \\
\hline P111 & jalapeño & Turuçu - RS & red & triangular & high \\
\hline P119 & pimenta ornamental & Rio Grande - RS & red & elongate & low \\
\hline $\mathrm{P} 122$ & pimenta ornamental & Pelotas - RS & red & triangular & low \\
\hline P143 & pimenta & Vassouras - RJ & red & elongate & medium \\
\hline P202 & jalapeño & Pelotas - RS & red & triangular & high \\
\hline $\mathrm{P} 258$ & pimenta ornamental & Pelotas - RS & red & triangular & medium \\
\hline P259 & pimenta & Pelotas - RS & yellow & triangular & medium \\
\hline P266 & pimenta & Palhoça - SC & red & triangular & medium \\
\hline P302 & pimenta ornamental & Pelotas - RS & dark red & elongate & medium \\
\hline
\end{tabular}

Information from passport data and morphological characterization of the accessions. 
readings were made with a spectrophotometer at wavelength of $470 \mathrm{~nm}$ using quartz cuvette, after it has been reset with the hexane solvent. A standard curve was established with the chlorogenic acid and the results were expressed as $\beta$-carotene.

\subsection{Quantification of antioxidant activity}

The determination of total antioxidant capacity was performed based on adapted method from Brand-Williams et al. (1995) using the stable radical DPPH (2,2-diphenyl-1-picrylhydrazyl). The DPPH was diluted in methanol to an absorbance of 1.1 at $515 \mathrm{~nm} \pm 0,02 \mathrm{UA}$. Samples of pepper $(5 \mathrm{~g})$ were homogenized with $20 \mathrm{ml}$ of solvent (methanol). The samples were centrifuged for 15 minutes at $25,000 \mathrm{rpm}$ in $4^{\circ} \mathrm{C}$ refrigerated centrifuge and the supernatant was collected. An aliquot of $200 \mu \mathrm{L}$ of the supernatant was added to $3.8 \mathrm{~mL}$ of DPPH reagent in a falcon tube and were shaken on a vortex mixer. The sample remained reacting for 24 hours in the dark at room temperature. The absorbance was measured by spectrophotometer at wavelength of $515 \mathrm{~nm}$ using a quartz cuvette. A standard curve was established for trolox.

\subsection{Statistical analysis}

The data were subjected to multivariate statistical analysis, by mean comparisons, using the statistical software SAS 9.2 (SAS Institute, 2011). Histograms were made with the aid of Microsoft Office Excel.

\section{Results}

The data from chemical analysis showed the presence of genetic variability in the accessions of Capsicum annuum evaluated. Data were displayed graphically in Figure 1, to view the content of total phenolics, anthocyanins, carotenoids and antioxidant activity.
Regarding phenolic compounds there was a formation of five distinct groups (Table 2). The values ranged from 324.02 to $946.3 \mathrm{mg} / 100 \mathrm{~g}$ fresh weight, and P119 accession (Figure 2) was the highlight, belonging to the group with the highest concentrations. The P202 accession showed the lowest value for phenolic compounds, belonging to the group with the lowest concentrations.

The P77 accession (Figure 2) was the highlight for anthocyanin when compared to other accessions (Table 2). Thus, for having immature fruit color dark violet, changing to dark red when ripe, the P77 had anthocyanins value equal to $4.92 \mathrm{mg} / 100 \mathrm{~g}$ fresh weight, much higher when compared to other accessions. The P259 accession (Figure 2), which has ripe fruit yellow, showed the lowest value for anthocyanins, obtaining a value of $0.15 \mathrm{mg} / 100 \mathrm{~g}$ for fresh weight

The P39 and P143 accessions showed high values for carotenoids (Figure 2). Both remained in the group of higher concentrations, and obtained values equal to 134.83 and $147.72 \mathrm{mg} / 100 \mathrm{~g}$ for fresh weight, respectively. Six distinct groups were formed, showing great variability in this aspect, which values ranged from 1.54 to $147.72 \mathrm{mg} / 100 \mathrm{~g}$ fresh weight.

The accessions showed large amplitude of variation for antioxidant capacity (Figure 1). Five groups were formed (Table 2) by Tukey test. It is worth noting the P119 accession (Figure 2), that showed high antioxidant potential, with $4419.37 \mu \mathrm{g} . \mathrm{g}^{-1}$, in contrast to the lowest value observed, $1174.5 \mu \mathrm{g} \cdot \mathrm{g}^{-1}$ (P202 accession).

There was good correlation $(r=0.675)$ between the phenolic compounds content and antioxidant activity in the Capsicum annuum accessions (Figure 3A). In contrast, the correlation between antioxidant activity and anthocyanins was low (Figure 3B), as well as the correlation between carotenoids and antioxidant activity (Figure 3C).

Table 2. Total content of phenolic compounds, anthocyanins, carotenoids and antioxidant activity of Capsicum annuum accessions peppers from Capsicum Genebank of Embrapa Temperate Agriculture (Pelotas, RS, Brazil).

\begin{tabular}{ccccc}
\hline Accessions & Phenolic compounds $^{1}$ & Anthocyanins $^{2}$ & Carotenoids $^{3}$ & Antioxidant activity $^{4}$ \\
\hline P7 & $599.97 \pm 46.4 \mathrm{bc}$ & $0.44 \pm 0.0 \mathrm{de}$ & $42.06 \pm 2.2 \mathrm{cde}$ & $2997.90 \pm 156.5 \mathrm{bc}$ \\
P22 & $629.04 \pm 51.4 \mathrm{bc}$ & $0.47 \pm 0.0 \mathrm{de}$ & $85.09 \pm 2.0 \mathrm{~b}$ & $2985.72 \pm 207.7 \mathrm{bc}$ \\
P39 & $524.22 \pm 37.1 \mathrm{~cd}$ & $1.05 \pm 0.1 \mathrm{~cd}$ & $134.83 \pm 10.2 \mathrm{a}$ & $2720.96 \pm 209.4 \mathrm{bcd}$ \\
P58 & $513.69 \pm 10.4 \mathrm{~cd}$ & $0.41 \pm 0.0 \mathrm{de}$ & $20.68 \pm 3.0 \mathrm{def}$ & $1877.57 \pm 305.8 \mathrm{cde}$ \\
P77 & $629.36 \pm 19.3 \mathrm{bc}$ & $4.92 \pm 0.6 \mathrm{a}$ & $84.16 \pm 4.2 \mathrm{~b}$ & $2692.85 \pm 67.0 \mathrm{bcd}$ \\
P111 & $373.70 \pm 11.7 \mathrm{de}$ & $0.68 \pm 0.1 \mathrm{cde}$ & $25.10 \pm 1.6 \mathrm{def}$ & $1763.92 \pm 125.4 \mathrm{de}$ \\
P119 & $946.33 \pm 20.6 \mathrm{a}$ & $0.83 \pm 0.0 \mathrm{cde}$ & $48.57 \pm 2.9 \mathrm{cde}$ & $4419.37 \pm 84.8 \mathrm{a}$ \\
P122 & $727.18 \pm 44.3 \mathrm{~b}$ & $0.34 \pm 0.1 \mathrm{de}$ & $44.32 \pm 6.0 \mathrm{cde}$ & $2384.39 \pm 323.7 \mathrm{bcd}$ \\
P143 & $727.54 \pm 18.3 \mathrm{~b}$ & $1.55 \pm 0.1 \mathrm{bc}$ & $147.72 \pm 9.1 \mathrm{a}$ & $3405.43 \pm 278.2 \mathrm{ab}$ \\
P202 & $324.02 \pm 22.5 \mathrm{e}$ & $0.85 \pm 0.1 \mathrm{cde}$ & $28.34 \pm 0.4 \mathrm{cdef}$ & $1174.58 \pm 32.2 \mathrm{e}$ \\
P258 & $602.74 \pm 46.7 \mathrm{bc}$ & $0.42 \pm 0.0 \mathrm{de}$ & $50.38 \pm 5.2 \mathrm{~cd}$ & $2495.39 \pm 184.3 \mathrm{bcd}$ \\
P259 & $704.91 \pm 40.7 \mathrm{~b}$ & $0.15 \pm 0.0 \mathrm{e}$ & $1.54 \pm 0.2 \mathrm{f}$ & $2589.74 \pm 369.2 \mathrm{bcd}$ \\
P266 & $601.84 \pm 12.8 \mathrm{bc}$ & $0.41 \pm 0.0 \mathrm{de}$ & $59.41 \pm 13.4 \mathrm{cb}$ & $2307.93 \pm 109.9 \mathrm{bcde}$ \\
P302 & $724.77 \pm 25.2 \mathrm{~b}$ & $2.45 \pm 0.1 \mathrm{~b}$ & $3439.12 \pm 235.7 \mathrm{ab}$ \\
\hline
\end{tabular}

${ }^{1}$ Total phenolic compounds expressed in mg equivalent chlorogenic acid / $100 \mathrm{~g}$ fresh weight. ${ }^{2}$ Total anthocyanins expressed in mg equivalent cyanidin-3-glucoside / $100 \mathrm{~g}$ fresh weight. ${ }^{3}$ Total carotenoids expressed in $\beta$-carotene equivalent / $100 \mathrm{mg}$ fresh weight. ${ }^{4}$ Total antioxidant activity expressed in mg trolox equivalent / $\mathrm{g}$ fresh weight. Means followed by the same letter, in each column, do not differ significantly by Tukey test at $5 \%$ probability of error. 
Phenolic Compounds

(mg equivalent chlorogenic acid /100 g fresh weight)

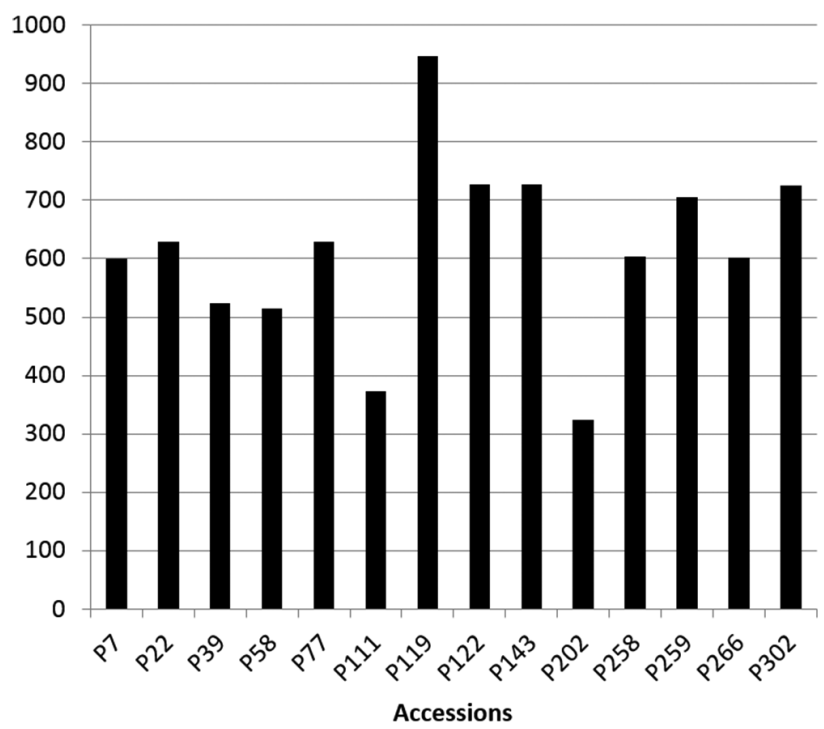

Carotenoids

( $\beta$-carotene equivalent /100 $\mathrm{mg}$ fresh weight)

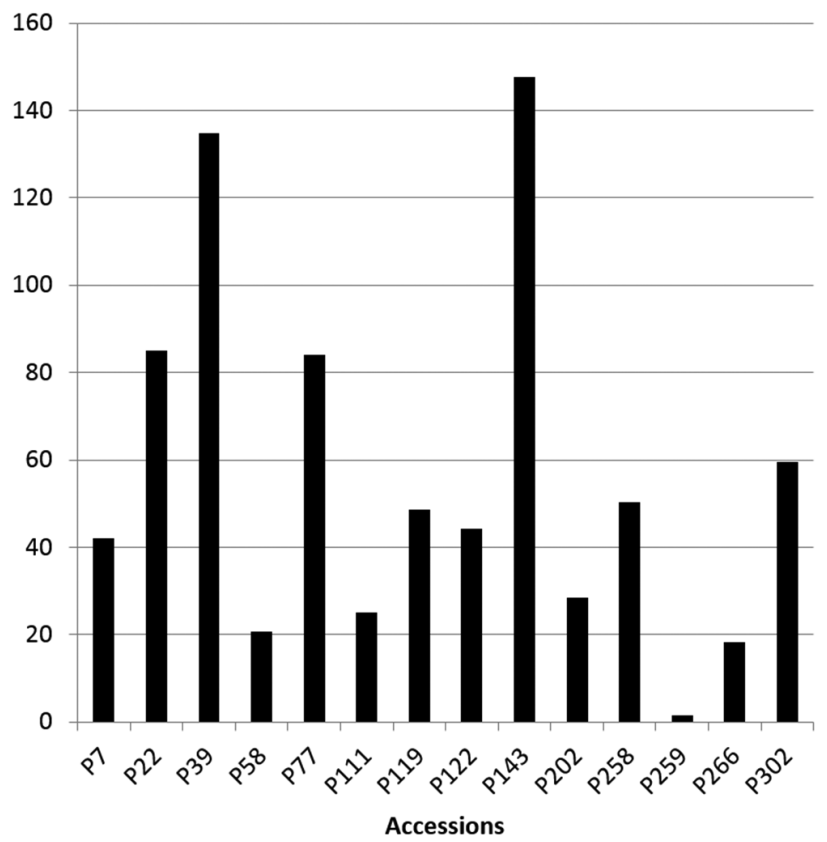

Anthocyanins

(mg equivalent cyanidin-3-glucoside/100 g fresh weight)

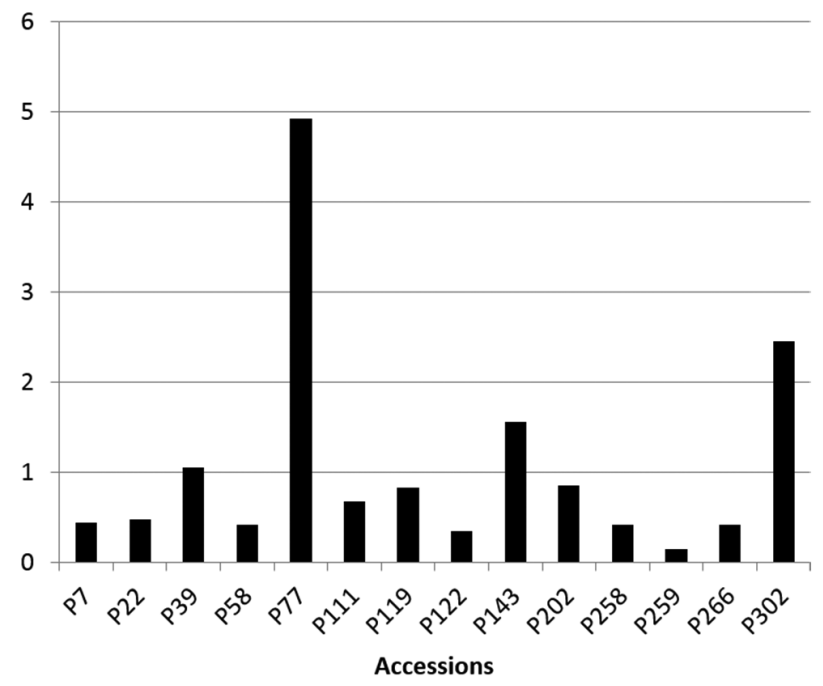

Antioxidant Activity

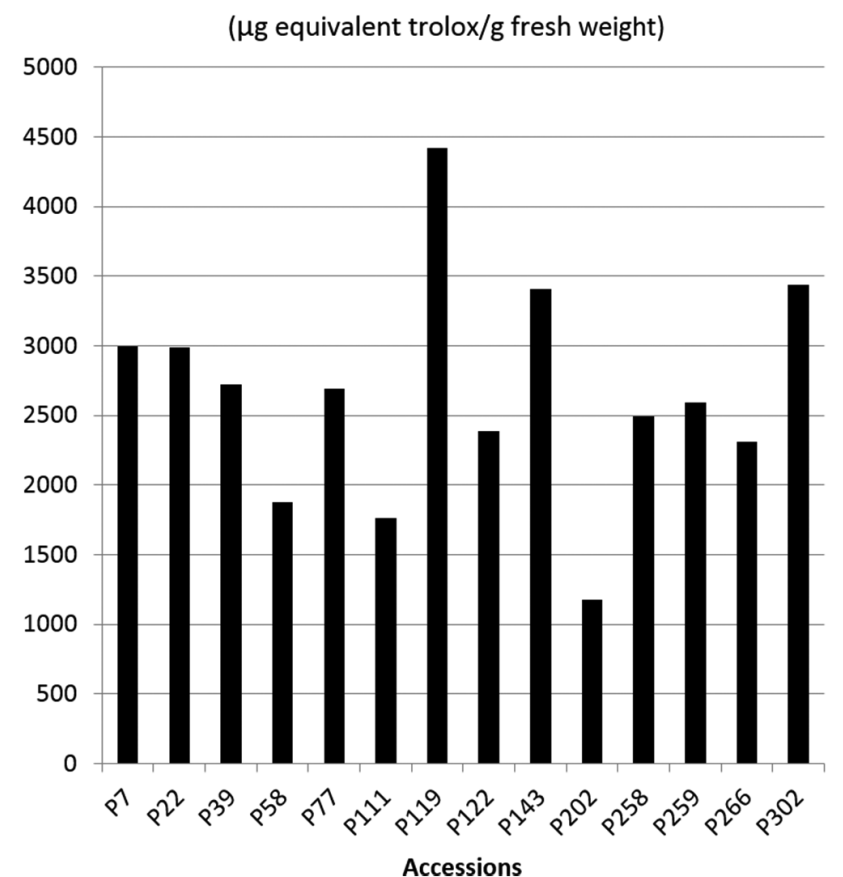

Figure 1. Bioactive compounds content of Capsicum annuum peppers from Capsicum Genebank of Embrapa Temperate Agriculture (Pelotas, RS, Brazil).

\section{Discussion}

Phenolic compounds are substances that perform an important role in the growth and reproduction of plants, providing protection against pathogens and predators well as contributing to the color and sensory characteristics of fruits and vegetables. Peppers are on the top in ranking of vegetables with high concentration of phenolic compounds, being higher than spinach, broccoli and garlic (Kevers et al., 2007).
Performing the morphological characterization of C. annuum accessions from the Capsicum Genebank of Embrapa Temperate Agriculture, Büttow et al. (2010) also highlighted the P77 compared to other accessions analyzed. According to those authors, due to high concentration of anthocyanin in plant, that determines her violet leaves, corolla and immature fruits, this accession can be indicated as an ornamental plant. According Pimenta et al. (2012) fruit colors ranging from orange to purple are attributed to flavonoid compounds which comprise the anthocyanins. 

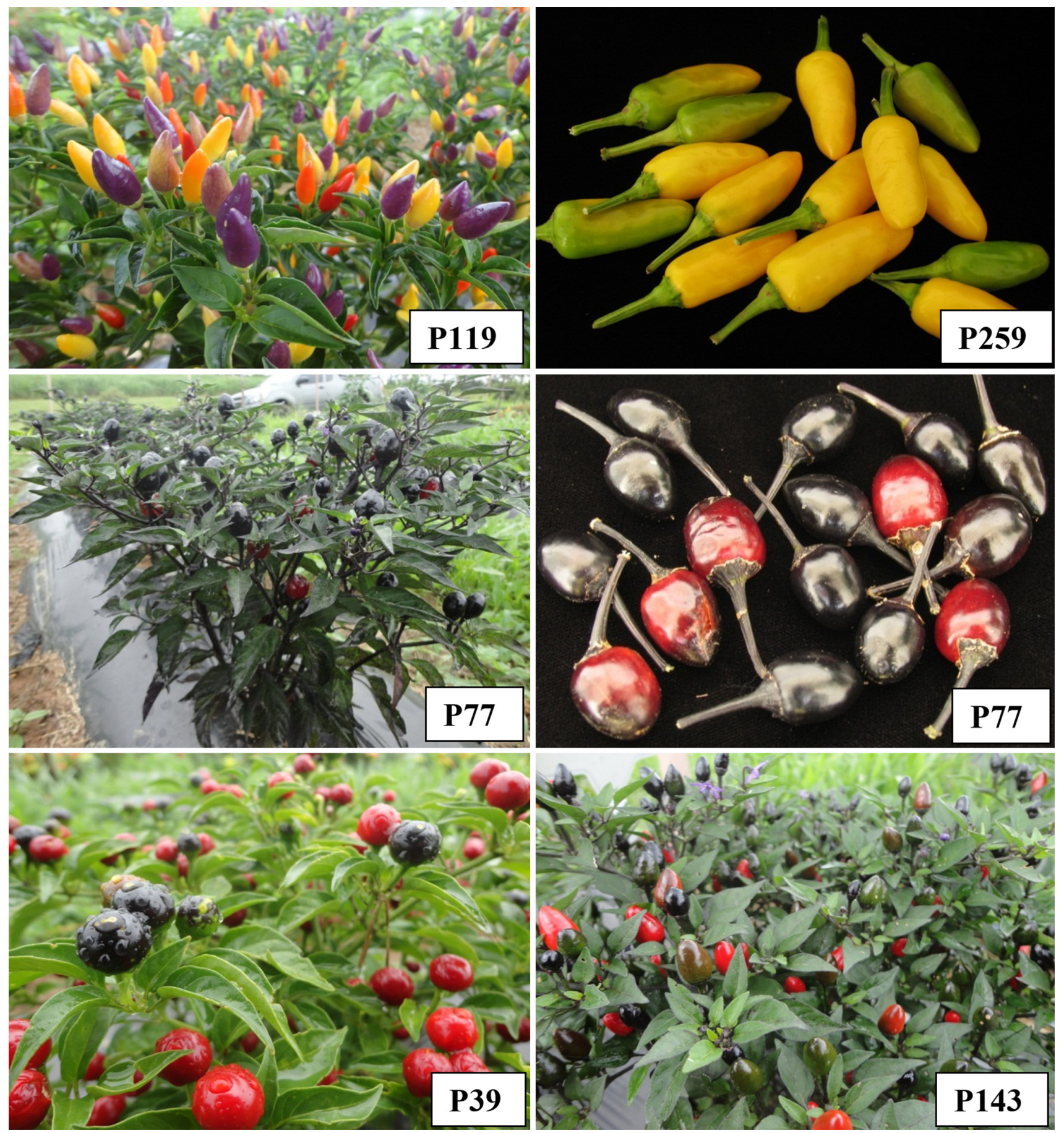

Figure 2. Accessions of Capsicum annuum peppers evaluated for synthesis of bioactive compounds. Accession P119, which showed the highest content of phenolic compounds, with fruits at different stages of maturation. Accession P259, which presented the lowest content of anthocyanins. Unripe (green) and ripe (yellow) fruits. Accession P77, which showed the highest content of anthocyanins. Plant in the field (left) and fruit at different stages of maturation (right). Accessions P39 and P143, which showed high levels of carotenoids.

Therefore, lower values obtained for the content of anthocyanin for accession P259 were expected, because yellow fruits are not within the color range reported by the authors. The levels of pigments in peppers fruits are influenced by genetic factors, degree of ripening fruits and climatic conditions (Ribeiro \& Reifschneider, 2008). Besides contributing to flower and fruit colors, anthocyanin act as UV filter on the leaves. In some plant species are associated with resistance to pathogens, and act improving and regulating photosynthesis (Kato et al., 2012).

Carotenoids are also important to determination of peppers fruit color, being the red color attributed to capsanthin, which represents $60 \%$ of total carotenoid (Lutz \& Freitas, 2008). Large variability was found in production of carotenoids in ripe fruits of different species of Capsicum (Ha et al., 2007). Other species also 

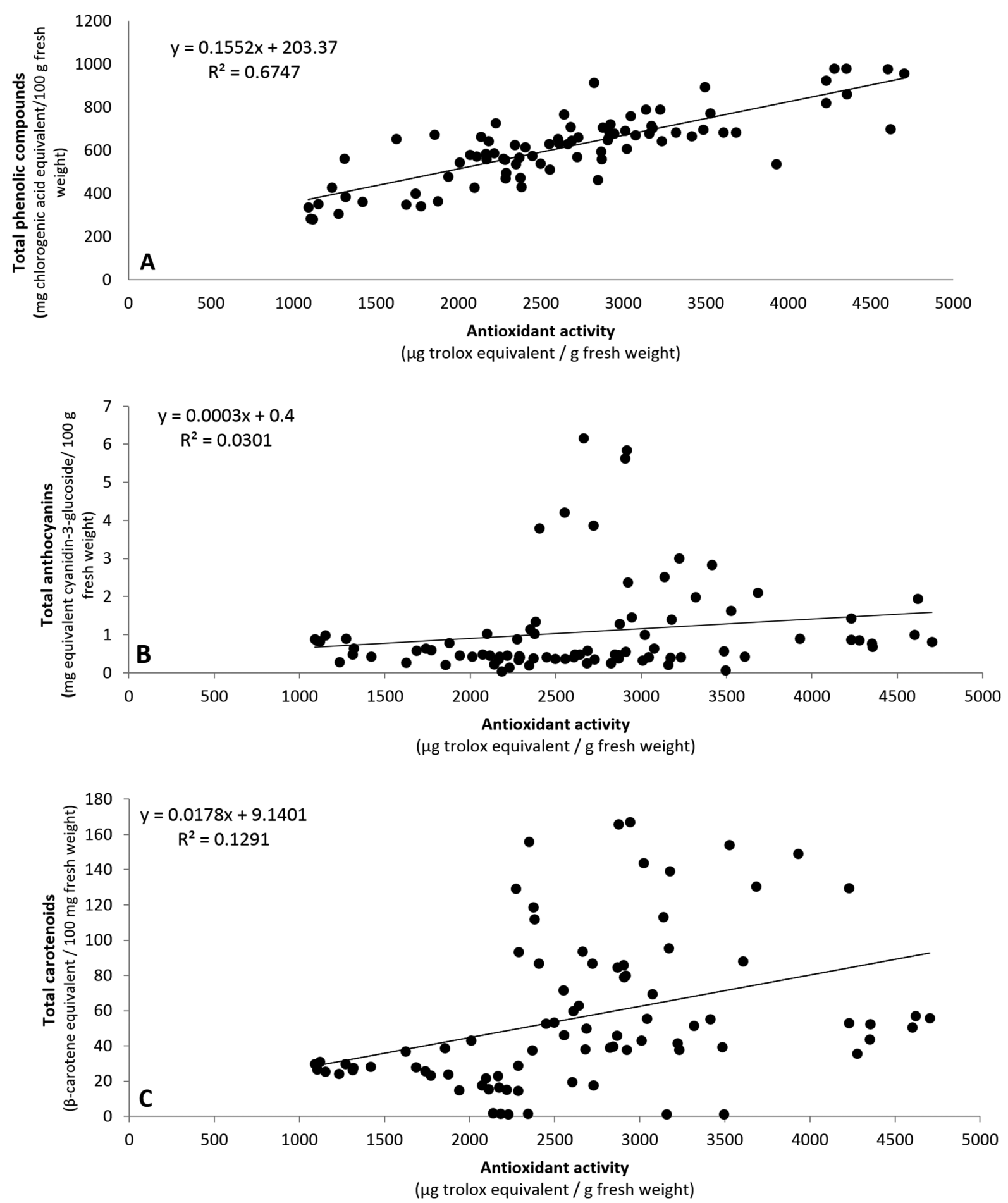

Figure 3. Correlations among bioactive compounds evaluated in Capsicum annuum accessions. (A) Correlation between antioxidant activity and phenolic compounds; (B) Correlation between antioxidant activity and anthocyanins; (C) Correlation between antioxidant activity and total carotenoids.

showed variability for carotenoids production. Examples such as yellow bell peppers (Capsicum annuum) and pumpkin (Cucurbita maxima) had on average 411 and $684 \mathrm{mg} / 100 \mathrm{~g}$ fresh weight of total carotenoids, respectively (Rodriguez-Amaya et al., 2008).

The antioxidant potential of $\mathrm{P} 119$ accession ( $\left.4419.37 \mu \mathrm{g} \cdot \mathrm{g}^{-1}\right)$ was higher than those obtained in Capsicum baccatum by
Neitzke (2012) and Vasconcelos (2012), where the highlighted accessions produced $1827.06^{-1} \mu \mathrm{g} . \mathrm{g}$ (P13) and $1573.01^{-1} \mu \mathrm{g} . \mathrm{g}$ (P8), respectively.

Koca \& Karadeniz (2009) noted linear correlation between antioxidant activity and total phenolic compounds content from $r=0.981$ when evaluated blueberry fruit. It should be noted 
that other compounds present in the mature fruits of pepper, beyond capsaicin, also contribute to antioxidant activity, such as ascorbic acid (Antonious et al., 2009).

The results of this study evidenced that P119 and P302 accessions showed highest antioxidant activity and concentration of phenolic compounds. The P77 and P302 accessions showed highest concentration of anthocyanin. P39 and P143 were the accessions that exhibited highest production of carotenoids. These highlighted accessions can be selected as good sources of natural antioxidants. Moreover, they can be exploited in plant breeding programs aiming to obtain cultivars with high potential for promoting consumers health. It is worth mentioning once again, P119 and P302 accessions that besides having characteristics that favor the use as ornamental plants (Büttow et al., 2010) also have high levels of antioxidant activity and phenolic compounds, further increasing the potential of these two accessions in plant breeding.

\section{Conclusions}

There is a great genetic variability for production of bioactive compounds in fruits of Capsicum annuum accessions from Capsicum Genebank of Embrapa Temperate Agriculture. The P39, P77, P119, P143 and P302 accessions have high levels of antioxidant compounds, which are strongly indicated to be used in breeding programs of Capsicum peppers.

\section{Acknowledgements}

The authors thank CNPq and CAPES by providing scholarships and financial support.

\section{References}

Alvarez-Parrilla, E., De La Rosa, L. A., Amarowicz, R., \& Shahidi, F. (2012). Protective effect of fresh and processed Jalapeño and Serrano peppers against food lipid and human LDL cholesterol oxidation. Food Chemistry, 133(3), 827-834. http://dx.doi.org/10.1016/j. foodchem.2012.01.100

Antonious, G. F., Lobel, L., Kochhar, T., Berke, T., \& Jarret, R. L. (2009). Antioxidants in Capsicum chinense: variation among countries of origin. Journal of Environmental Science and Health, 44(6), 621-626. http://dx.doi.org/10.1080/03601230903000727. PMid:20183071.

Brand-Williams, W., Cuvelier, M. E., \& Berset, C. (1995). Use of a Free Radical method to evaluate antioxidant activity. LebensmittelWissenschaft \& Technologie, 28(1), 25-30. Retrieved from http:// www.sciencedirect.com/science/article/pii/S0023643895800085.

Büttow, M. W., Barbieri, R. L., Neitzke, R. S., Heiden, G., \& Carvalho, F. I. F. (2010). Diversidade genética entre acessos de pimentas e pimentões da Embrapa Clima Temperado. Ciência Rural, 40(6), 1264-1269. http://dx.doi.org/10.1590/S0103-84782010000600004.

Carvalho, S. I. C., \& Bianchetti, L. B. (2008). Botânica e recursos genéticos. In C. S. Ribeiro, S. I. C. Carvalho, G. P. Henz \& F. J. B. Reifschneider (Eds.), Pimentas Capsicum (chap. 5, pp. 39-54). Brasília: Embrapa Hortaliças.

Fuleki, T., \& Francis, F. J. (1968). Quantitative methods for anthocyanins extraction and determination of total anthocyanin in cranberries. Journal of Food Science, 33(1), 72-77. http://dx.doi. org/10.1111/j.1365-2621.1968.tb00887.x.
Ha, S. H., Kim, J. B., Park, J. S., Lee, S. W., \& Cho, K. J. (2007). A comparison of the carotenoid accumulation in Capsicum varieties that show different ripening colours: deletion of the capsanthincapsorubin synthase gene is not a prerequisite for the formation of a yellow pepper. Journal of Experimental Botany, 58(12), 3135-3144. http://dx.doi.org/10.1093/jxb/erm132. PMid:17728301.

Hwang, D. G., Park, J. H., Lim, J. Y., Kim, D., Choi, Y., Kim, S., Reeves, G., Yeom, S. I., Lee, J. S., Park, M., Kim, S., Choi, I. Y., Choi, D., \& Shin, C. (2013). The hot pepper (Capsicum annuum) microRNA transcriptome reveals novel and conserved targets: a foundation for understanding MicroRNA functional roles in hot pepper. PLoS One, 8(5), e64238. http://dx.doi.org/10.1371/journal.pone.0064238. PMid:23737975.

Kato, C. G., Tonhi, C. D., \& Clemente, E. (2012). Antocianinas de uvas (Vitis vinifera) produzidas em sistema convencional. Revista Brasileira de Tecnologia Agroindustrial, 6(2), 809-821. Retrieved from https:// periodicos.utfpr.edu.br/rbta/article/view/979/864.

Kevers, C., Falkowski, M., Tabart, J., Defraigne, J. O., Dommes, J., \& Pincemail, J. (2007). Evolution of antioxidant capacity during storage of selected fruits and vegetables. Journal of Agricultural and Food Chemistry, 55(21), 8596-8603. http://dx.doi.org/10.1021/jf071736j. PMid:17880151.

Koca, I., \& Karadeniz, B. (2009). Antioxidant properties of blackberry and blueberry fruits grown in the Black Sea Region of Turkey. Scientia Horticulturae, 121(4), 447-450. http://dx.doi.org/10.1016/j. scienta.2009.03.015.

Lutz, D. L., \& Freitas, S. C. (2008). Valor nutricional. In C. S. C. Ribeiro, S. I. C. Carvalho, G. P. Henz \& F. J. B. Reifschneider (Eds.), Pimentas Capsicum (chap. 4, pp. 31-38). Brasília: Embrapa Hortaliças.

Mateos, R. M., Jiménez, A., Román, P., Romojaro, F., Bacarizo, S., Leterrier, M., Gómez, M., Sevilla, F., Del Río, L. A., Corpas, F. J., \& Palma, J. M. (2013). Antioxidant systems from pepper (Capsicum annuum $\mathrm{L}$.): involvement in the response to temperature changes in ripe fruits. International Journal of Molecular Sciences, 14(5), 95569580. http://dx.doi.org/10.3390/ijms14059556. PMid:23644886.

Moraes, L. P., Da Paz, M. F., Sanjines-Argandoña, E. J., Silva, L. R., \& Zago, T. D. (2013). Compostos fenólicos e atividade antioxidante de molho de pimenta "Dedo-de-Moça" fermentado. Biochemistry and Biotechnology Reports, 1(2), 33-38. Retrieved from http://www.uel. br/revistas/uel/index.php/bbr/article/view/14551/12349.

Morales-Soto, A., Gómez-Caravaca, A. M., García-Salas, P., SeguraCarretero, A., \& Fernández-Gutiérrez, A. (2013). High-performance liquid chromatography coupled to diode array and electrospray time-of-flight mass spectrometry detectors for a comprehensive characterization of phenolic and other polar compounds in three pepper (Capsicum annuum) samples. Food Research International, 51(2), 977-9842. Retieved from http://www.sciencedirect.com/ science/article/pii/S0963996913001154.

Neitzke, R. S. (2012) Recursos genéticos de pimentas do gênero Capsicum - explorando a multiplicidade de usos (Doctoral thesis). Universidade Federal de Pelotas, Pelotas.

Ornelas-Paz, J. J., Martínez-Burrola, J. M., Ruiz-Cruz, S., SantanaRodríguez, V., Ibarra-Junquera, V., Olivas, G. I., \& Pérez-Martínez, J. D. (2010). Effect of cooking on the capsaicinoids and phenolics contents of Mexican peppers. Food Chemistry, 119(4), 1619-1625. http://dx.doi.org/10.1016/j.foodchem.2009.09.054.

Park, S., Jeong, W. Y., Lee, J. H., Kim, Y.-H., Jeong, S. W., Kim, G.-S., Bae, D. W., Lim, C.-S., Jin, J. S., Lee, S. J., \& Shin, S. C. (2012). Determination of polyphenol levels variation in Capsicum annuum cv. Chelsea (yellow bell pepper) infected by anthracnose (Colletotrichum gloeosporioides) using liquid chromatography-tandem 
mass spectrometry. Food Chemistry, 130(4), 981-985. http://dx.doi. org/10.1016/j.foodchem.2011.08.026.

Pimenta, S. M., Zambrano, F., \& Venturini, F. W. G. (2012). Suco integral de amora (Morus nigra) obtido através de prensagem e despolpamento: rendimento e caracterização físico-química. Alimentos e Nutrição, 23(2), 335-339. Retrieved from http://serv-bib.fcfar.unesp.br/seer/ index.php/alimentos/article/view/1566/1566.

Ribeiro, C. S. C., \& Reifschneider, F. J. B. (2008). Genética e melhoramento. In C. S. C. Ribeiro, S. I. C. Carvalho, G. P. Henz \& F. J. B. Reifschneider (Eds.), Pimentas Capsicum (cap. 6, p. 55-69). Brasília: Embrapa Hortaliças.

Rodriguez-Amaya, D. B., Kimura, M., \& Amaya-Farfan, J. (2008). Fontes brasileiras de carotenoides: tabela brasileira de composição de carotenoides em alimentos. Brasília: Ministério do Meio Ambiente.

SAS Institute. (2011). The SAS system for Windows. Cary: SAS Institute. Release 9.2.
Shetty, A. A., Magadum, S., \& Managanvi, K. (2013). Vegetables as sources of antioxidants. Journal of Food \& Nutritional Disorders, 2(1), 1-5. http://dx.doi.org/10.4172/2324-9323.1000104. PMid:25328903.

Swain, T., \& Hillis, W. E. (1959). The phenolic constituents of Prunus domestica - the quantitative analysis of phenolic constituents. Journal of the Science of Food and Agriculture, 10(1), 63-68. http://dx.doi. org/10.1002/jsfa.2740100110.

Talcott, S. T., \& Howard, L. R. (1999). Phenolic autoxidation is responsible for color degradation in processed carrot puree. Journal of Agricultural and Food Chemistry, 47(5), 2109-2115. http://dx.doi.org/10.1021/ jf981134n. PMid:10552504.

Vasconcelos, C. S. (2012). Avaliação agronômica e caracterização da produção de compostos bioativos em variedades crioulas de pimentas (Capsicum baccatum) (Masters dissertation). Universidade Federal de Pelotas, Pelotas. 